\title{
STRATEGI PENGEMBANGAN PONDOK PESANTREN DALAM ERA GLOBALISASI DI KABUPATEN BANYUWANGI
}

\author{
Abdul Kholiq Syafa'at \\ Fakultas Syariah dan Hukum Universitas Islam Negeri (UIN) \\ Sunan Ampel Surabaya \\ kholiq_sy@yahoo.com \\ Siti Aimah, Lely Ana Ferawati Ekaningsih, Mahbub \\ Sekolah Tinggi Agama Islam Darussalam (STAIDA) Banyuwangi \\ staida_bwi@yaboo.co.id
}

\begin{abstract}
This study was conducted to identify and analyze the external factors that can lead to opportunities and threats, as well as internal factors are the strengths and weaknesses for boarding, so we can know what strategies are suitable to appliedi schools in an effort to increase its presence as an Islamic educational institutions in the environment conditions that have changed into modern one. The focus of research is the development strategy of boarding school in an effort to maintain its existence as educational institutions in the era of globalization. This type of research is qualitative research. Data analysis methods used are: a qualitative analysis, which is a series of activities to analyze the data in the study objects that are not expressed in the figures using SWOT analysis. Research results indicate that the development of appropriate strategies to be implemented in the pesantren of Banyuwangi regency there are :1) development of Islamic educational institutions there are two, namely: consistent and adaptive, 2) renewal of pesantren management by application of professional management, 3) improving resource there are namely: enhancement of human resources and improvement of Natural Resources.
\end{abstract}

Keywords: Islamic educational institutions,strategy 
Abdul Kholiq Syafa'at, dkk.

\begin{abstract}
Abstrak
Penelitian ini dilakukan dengan tujuan untuk mengidentifikasi dan menganalisis faktor eksternal yang dapat menimbulkan peluang dan ancaman, serta faktor internal yang merupakan kekuatan dan kelemahan bagi pesantren, sebingga dapat diketabui strategi apa yang cocok untuk diterapkan pada pesantren dalam upaya meningkatkan eksistensinya sebagai lembaga pendidikan Islam di kondisi lingkungan yang telah berubah modern. Fokus penelitian adalab strategi pengembangan pondok pesantren dalam upaya mempertabankan eksistensinya sebagai lembaga pendidikan di era globalisasi. Jenis penelitian adalab penelitian kualitatif. Metode analisis data yang digunakan adalah: Analisis kualitatif, yaitu serangkaian kegiatan menganalisis data dalam obyek penelitian yang tidak dinyatakan dalam angka-angka tetapi menggunakan analisis SWOT. Hasil Penelitian menunjukkan babwa strategi pengembangan yang tepat untuk diterapkan pesantren di Kabupaten Banyuwangi diantaranya; 1) strategi pengembangan lembaga pendidikan Islam ada 2, yaitu: konsisten dan adaptif, 2) strategi pembaruan manajemen pesantren yakni dengan penerapan manajemen profesional, 3) strategi peningkatan sumber daya pesantren ada 2, yaitu: peningkatan Sumber Daya Insani dan peningkatan Sumber Daya Alam.
\end{abstract}

Kata kunci: lembaga pendidikan Islam, strategi

\title{
Pendahuluan
}

Pada era globalisasi, pondok pesantren dihadapkan pada beberapa perubahan sosial budaya yang tidak terelakkan, pondok pesantren tidak dapat melepaskan diri dari perubahan-perubahan. Kemajuan teknologi informasi dapat menembus benteng budaya pondok pesantren. Dinamika sosial ekonomi telah mengharuskan pondok pesantren untuk tampil dalam persaingan dunia pasar bebas (free market), belum lagi sejumlah perkembangan lain yang terbungkus dalam dinamika masyarakat yang juga berujung pada pertanyaan tentang resistensi (ketahanan), responsibilitas (tanggung jawab), kapabilitas (kemampuan), dan kecanggihan pondok pesantren dalam tuntutan perubahan besar. Apakah pesantren mampu menghadapi konsekuensi logis dari perubahan-perubahan tersebut?. Usaha mencari alternatif jawaban itu relatif akan ditemukan bila 
diketahui dan dipahami secara persis antropologi internal dan eksternal pondok pesantren. Upaya ini meniscayakan penelanjangan yang jujur dan rela melepaskan diri dari segala asumsi negatif dan sikap apriori terhadap pondok pesantren(Suwendi, 2004:118).

Pesantren, dengan teologi yang dianutnya hingga kini, ditantang untuk menyikapi globalisasi secara kritis dan bijak. Pesantren harus mampu mencari solusi yang benar-benar mencerahkan, sehingga pada pada suatu sisi, dapat menumbuh kembangkan kaum santri untuk memiliki wawasan yang luas, yang tidak gamang menghadapi modernitas, dan sekaligus tidak kehilangan identitas dan jati dirinya, dan pada sisi lain, dapat mengantarkan masyarakatnya menjadi komunitas yang menyadari tentang persoalan yang dihadapi dan mampu mengatasi dengan penuh kemandirian dan peradaban (Abdul A'la, 2006: 9).

Seiring dengan kebutuhan yang demikian cepat berkembang dan beragam serta kompleksitasnya masalah yang dihadapi, maka diperlukan adanya profesionalitas dalam rangka meningkatkan kualitas kinerja lembaga dakwah. Lembaga pesantren perlu berbenah diri untuk dapat berhasil memenuhi kebutuhan dan tuntutan masyarakat modern tersebut. Pesantren sebagai lembaga dakwah sekaligus sabagai lembaga pendidikan yang mencetak generasi penerus Islam yang handal dan profesional sesuai dengan perkembangan jaman, dituntut untuk mampu menawarkan pemahaman Islam yang modern dan universal. Di samping modernisasi ide, modernisasi kelembagaan organisasi juga harus dilakukan dengan penerapan proses manajemen yang benar .

Tantangan terbesar bagi keberhasilan sebuah lembaga dakwah seperti pesantren dalam mencapai tujuan adalah berubahnya jaman yang menuntut profesionalisme dalam pengelolaan lembaga, kualitas sumber daya pengelola, kemampuan pengelola dalam menyikapi kemajuan teknologi, serta meluluskan alumni yang berkualitas. Untuk bisa memenuhi hal tersebut suatu lembaga dakwah seperti pesantren dapat menerapkan dan mengaplikasikan konsep manajemen strategi dalam usaha mencapai tujuannya.

Dengan perencanaan strategi dapat membantu lembaga dakwah seperti pesantren untuk menangani kondisi yang berubah, 
membantu untuk merumuskan dan menyelesaikan isu-isu penting yang dihadapi. Dengan perencanaan stategi dapat membantu membangun kekuatan dan menarik manfaat dari peluang-peluang penting, sementara di lain pihak dapat juga mengurangi apa yang merupakan kelemahannya atau menghindari ancaman serius. Bahkan perencanaan strategi mampu membuat lebih efektif dalam kondisi lingkungan yang penuh ancaman.

Dari uraian latar belakang di atas, maka rumusan masalah yang akan diangkat dalam penelitian ini adalah: Apa saja faktor eksternal yang mempengaruhi pengembangan Pondok Pesantren yang ada di Kabupaten Banyuwangi?. Apa saja faktor internal yang mempengaruhi pengembangan Pondok Pesantren yang ada di Kabupaten Banyuwangi?. Bagaimanakah strategi pengembangan yang tepat untuk diterapkan pondok pesantren di Kabupaten Banyuwangi?Apa saja kebijakan yang bisa direkomendasikan kepada pemerintah daerah Kabupaten Banyuwangi terkait strategi pengembangan pesantren?

\section{Manajemen Strategi}

Strategi berasal dari bahasa Yunani stratogos yang artinya ilmu para jenderal untuk memenangkan suatu pertempuran dengan menggunakan sumber daya yang terbatas (Sihombing, 2000). Pengertian atau definisi Manajemen strategi dalam khasanah literatur ilmu manajemen memiliki cakupan yang luas, dan tidak ada suatu pengertian yang dianggap baku. Itulah sebabnya defenisi manajemen strategi berkembang luas tergantung pemahaman ataupun penafsiran seseorang.

Strategi menjadi suatu kerangka yang fundamental tempat suatu organisasi mampu menyatakan kontinuitasnya yang vital, sementara pada saat yang bersamaan ia akan memiliki kekuatan untuk menyesuaikan diri terhadap lingkungan yang selalu berubah. Dengan menggunakan manajemen strategik sebagai suatu kerangka kerja untuk menyelesaikan setiap masalah strategis didalam perusahaan, terutama yang berkaitan dengan persaingan, maka para menajer diajak untuk berpikir lebih kreatif atau berpikir secara strategik. Merancang Strategic Architecture dan Operasi dalam Dunia 
Pendidikan penting dilakukan setelah analisis lingkungan, lembaga pendidikan diharapkan mampu memperoleh gambaran yang cukup utuh mengenai kondisi eksternal dan kondisi internalnya. Dengan demikian faktor-faktor yang merupakan kekuatan, kelemahan, kesempatan dan ancaman sudah mampu terdefenisi dengan jelas. Berdasarkan hal ini, suatu institusi pendidikan kemudian dapat menentukan dan menetapkan arah yang ingin dituju dimasa depan.

\section{Pondok Pesantren}

Pondok pesantren adalah suatu lembaga pendidikan sekaligus lembaga dakwah Islam yang ada di Indonesia, pesantren pada dasarnya dibangun atas keinginan bersama antara dua komunitas yang saling bertemu yaitu santri (masyarakat) yang ingin menimba ilmu sebagai bekal hidup dan kyai/guru yang secara ikhlas ingin mengajarkan ilmu dan pengalamannya. Seperti yang dikatakan oleh Imam Tholkhah dan Ahmad Barizi dalam bukunya membuka jendela Pendidikan (2004:55), "Kyai dan santri adalah dua komunitas yang memiliki kesadaran yang sama untuk sacara bersama-sama membangun komunitas keagamaan yang disebut pesantren".

Pesantren di Indonesia baru diketahui keberadaan dan perkembangannya setelah abad ke 16. Karya-karya jawa klasik seperti serat cabolek dan serat centini mengungkapkan bahwa sejak permulaan abad ke 16 di Indonesia telah banyak di jumpai lembagalembaga yang mengajarkan berbagai kitab Islam klasik dalam bidang fiqih, aqidah, tasawuf, dan menjadi pusat-pusat penyiaran Islam yaitu pesantren.

Pada masa penjajahan, pesantren mengalami tekanan yang amat berat, pesantren memang memberikan pengajaran tentang cinta tanah air dan menanamkan sikap patriotik pada para santrinya. Karena, walaupun pada dasarnya hanya merupakan lembaga pendidikan keagamaan, namun lembaga ini juga mengutamakan dalam pembinaan mental dan spiritual para santrinya. Hal inilah yang menjadi kekhawatiran penjajah. Untuk menanggulangi hal yang demikian, pemerintah Hindia belanda kemudian menawarkan bentuk pendidikan yang modern dalam performa sekolah. Sekolahsekolah Hindia Belanda kemudian berkembang menyaingi 
keberadaan pesantren, sekolah-sekolah ini lebih bersifat pendidikan yang berorientai kepada kerja, dalam arti para lulusannya dapat memperoleh kerja melalui ijasah yang diberikan oleh sekolah tersebut. Untuk mengimbangai hal yang demikian, beberapa cendekiawan muslim Indonesia pada saat itu mencoba mendirikan sekolah-sekolah lebih berciri khas keIslaman yaitu madrasah. Mulailah pengajaran agama diperkenalkan melalui sistem sekolah modern. Akan tetapi sistem ini tidak serta merta diterima begitu saja. Sehingga mulai muncul dikotomi-dikotomi antara pesantren yang mengadopsi sistem sebagaimana pesantren didirikan pada awalnya atau lebih dikenal dengan istilah pesantren salaf dan kholaf atau modern.

Menurut Qomar (2007:6-7),tujuan umum pesantren adalah membina warga negara agar berkepribadian muslim sesuai dengan ajaran-ajaran agama Islam dan menanam rasa keagamaan tersebut pada semua segi kehidupan.

Ciri-ciri pesantren yang masih berpegang teguh pada nilainilai salafiyah menurut Sulthon dan Khusnurridlo (2006:12-13)dapat didefinisikan sebagai berikut: (1) Adanya hubungan yang akrab antara santri dan kyai, (2) Kepatuhan santri pada kyai, (3) Hidup hemat dan sederhana benar-benar diwujudkan dalam lingkungan pesantren, hidup mewah hampir tidak ditemukan di sana, (4) Kemandirian amat terasa di kehidupan pesantren, (5) Jiwa tolong menolong dan suasana persaudaraan (Ukhuwah Islamiyah) sangat mewarnai pergaulan di pesantren. (6) Disiplin sangat dianjurkan, (7) Keprihatinan untuk mencapai tujuan mulia, (8) Pemberian ijazah.

\section{Prinsip-prinsip pendidikan pesantren}

Keinginan dan kaidah yang terlaku di dalam kehidupan pesantren merupakan nilai pokok yang melandasi kehidupan dunia pesantren. Eksistensi pesantren menjadi kokoh karena dijiwai oleh apa yang dikenal dengan pasca jiwa pesantren menurut Tolkhah dan Barizi, 2004:55-56,yaitu: (1) Keikhlasan, (2) Kesederhanaan, (3) Kemandirian, (4) Bebas, (5) Ukhuwah Islamiyyah. 


\section{Metode Penelitian}

Fokus penelitian adalah strategi pengembangan pondok pesantren dalam upaya mempertahankan eksistensinya sebaga lembaga pendidikan di era globalisasi. Sedangkan jenis penelitian adalah penelitian kualitatif yang didefinisikan sebagai prosedur penelitian yang menghasilkan data deskriptif (berupa kata-kata yang tertulis atau lisan dari orang-orang dan perilaku yang diamati).

Lokasi/obyek penelitian adalah Pondok pesantren yang berada di kabupaten Banyuwangi dan pondok pesantren yang memiliki lembaga pendidikan formal serta telah diakui eksistensinya oleh pemerintah dan masyarakat yaitu:

a. Pondok Pesantren Darussalam Blokagung Tegalsari Banyuwangi

b. Pondok Pesantren Bustanulmakmur Canga'an Genteng Banyuwangi

c. Pondok Pesantren Mamba'ulhuda Krasak Tegalsari Banyuwangi

d. Pondok Pesantren Mamba'ululum Sumberberas Muncar Banyuwangi

e. Pondok Pesantren Darussholah Gumirih Singojuruh Banyuwangi

Data yang akan diambil berupa data primer dan data sekunder. Teknik pengumpulan data dengan menggunakan observasi dan dokumentasi. Informan penelitian diambil dengan tujuan penelitian yaitu 10 orang pengasuh pondok pesantren, 14 orang staf pengelola pondok pesantren, 15 orang tokoh agama dan 15 orang tokoh masyarakat, 10 orang alumni pesantren dan 6 orang dari dinas terkait. Jadi total informan untuk penggalian data pada 5 (lima) pesantren yang memiliki lembaga pendidikan formal di kabupaten Banyuwangi adalah sejumlah 70 orang.

Metode analisis data yang digunakan adalah: Analisis kualitatif, yaitu serangkaian kegiatan menganalisis data dalam obyek penelitian yang tidak dinyatakan dalam angka-angka yaitu menggunakan analisis Strength, Weaknes, Opportunity and Threat (SWOT) adalah suatu analisis yang membandingkan antara kekuatan dan kelemahan yang dimiliki oleh organisasi serta peluang dan ancaman yang terjadi dalam organisasi untuk memilih dan memilah alternatif strategi yang akan digunakan untuk mencapai tujuan organisasi. 
Abdul Kholiq Syafa'at, dkk.

\section{Analisis}

Pondok Pesantren Darussalam Blokagung Tegalsari Banyuwangi

Pesantren Darussalam Blokagung Tegalsari Banyuwangi merupakan lembaga pendidikan pesantren yang berada di daerah Banyuwangi Selatan wilayah Provinsi Jawa Timur, tepatnya \pm 12 KM dari kota Genteng dan Jajag serta $\pm 45 \mathrm{KM}$ dari kota Kabupaten Banyuwangi. KH. Mukhtar Syafa'at adalah tokoh pendiri berasal dari Desa Ploso Klaten Kediri Jawa Timur. Secara resmi berbadan hukum dan berbentuk yayasan dengan nama "Yayasan Pesantren Darussalam" dengan akte notaris Soesanto adi purnomo, SH. Nomor 31 tahun1978. Unit-unit lembaga pendidikan formal yang dimiliki Madrasah Diniyah al-Amiriyyah yang berafiliasi pada kementerian agama Republik Indonesia direktorat pesantren dan diniyah. Kemudian juga membuka Madrasah Tsanawiyah (MTs) al-Amiriyyah, Madrasah Aliyah (MA) al-Amiriyyah yang berafiliasi pada kementerian agama Republik Indonesia direktorat pendidikan Islam. Selain itu juga membuka unit pendidikan yang berafiliasi pada kementerian pendidikan nasional yaitu Pendidikan Anak Usia Dini, Taman Kanak-kanak (TK) Darussalam, Sekolah Dasar (SD) Darussalam, Sekolah Menengah Pertama (SMP) Darussalam, Sekolah Menengah Atas (SMA) Darussalam, Sekolah Menengah Kejuruan (SMK) Darussalam. Serta membuka unit pendidikan yang berafiliasi pada kementerian agama Republik Indonesia direktorat pendidikan tinggi Islam yakni Sekolah Tinggi Agama Islam (STAI) Darussalam atau yang kemudian dikenal dengan nama STAIDA. Adapun jumlah santri pesantren Darussalam Blokagung 4.121 santri, berasal dari seluruh kepulauan Nusantara dengan berbagai wilayah/daerah mulai sabang sampai merauke.

\section{Faktor eksternal yang mempengarubi pengembangan}

a) Peluang:

1) Pengelolaan pesantren yang mengutamakan high moral adalah statemen masyarakat yang menguntungkan untuk menjaga citra tersebut dalam aktualiasasi pengembangan pesantren. a) pengakuan masyarakat bahwa pesantren adalah benteng moral bangsa, poin ini juga memberikan peluang 
untuk membuktikan kepada masyarakat bahwa pendidikan moral/etika adalah hal yang paling diutamakan.b) pengakuan masyarakat bahwa pesantren adalah basis pendidikan Islam, dengan pengakuan ini pesantren juga berpeluang untuk mengembangkan pesantren. c) kepercayaan masyarakat dan pemerintah, peluang ini bermanfaat untuk membuktikan eksistensinya sebagai lembaga pendidikan Islam, khususnya yang dikelola pesantren, dengan menorehkan prestasi santrinya di tingkat daerah, wilayah dan nasional, sehingga muncul kepercayaan masyarakat dan pemerintah dengan pengakuan bahwa yayasan pesantren Darussalam Blokagung saat ini menjadi yayasan pesantren terbesar dan terlengkap unit pendidikannya di daerah kabupaten Banyuwangi. d) dukungan tokoh agama, tokoh masyarakat dan pemerintah, hal ini menjadi poin/peluang penting bagi penyelenggaraan pendidikan dan kegiatan pesantren, karena dengan dukungan tokoh agama, tokoh masyarakat dan pemerintah melalui pola pengelolaan pendidikan berbasis pesantren yang berafiliasi pada kementerian agama untuk kajian pendidikan agama Islam dan berafiliasi pada kementerian pendidikan nasional untuk kajian pendidikan ilmu pengetahuan umum. e) dukungan orang tua siswa/santri dan alumni, sebagai bagian dari stakeholder, orang tua siswa/santri dan alumni dukungannya memberikan peluang bagi upaya pengembangan pesantren. f) adanya workshop dan pelatihan profesional pegawai oleh pemerintah maupun swasta, poin ini juga menjadi peluang untuk mengikutsertakan pegawainya mengikuti workshop dan pelatihan tersebut dalam rangka mendukung profesionalitasnya. g) adanya kesempatan bagi pegawai untuk melanjutkan pendidikan yang lebih tinggi dengan beasiswa dari pemerintah maupun swasta, poin ini juga merupakan peluang yang sangat berpengaruh positif terhadap perkembangan profesionalitas pegawai yang direkomendasikan melanjutkan pendidikannya ke tingkat lebih tinggi agar bisa memberikan kontribusi yang lebih baik pada pengembangan pesantren. $h$ ) apresiasi yang baik dari orang tua siswa/santri, item ini merupakan peluang sekaligus 
menjadi wacana penting bagi pengembangan pesantren. i) minat yang baik dari masyarakat, adalah peluang yang bisa dimanfaatkan untuk mendapatkan input dan memprosesnya dengan kualiatas pendidikan yang baik.

2) Adanya bantuan dana dari pemerintah dan swasta untuk penyediaan pra sarana dan sarana pendidikan membantu pesantren dalam mencukupi keterbatasan anggaran dana pembangunan. a) bantuan dari pemerintah, dengan poin ini pesantren berpeluang untuk meningkatkan kualitas pendidikan melalui pemenuhan kebutuhan fasilitas yang memadai bagi penyelenggaraan pendidikan dan kegiatan pesantren. b) bantuan dari swasta, poin ini juga memberikan peluang bagi peningkatan pendidikan pesantren dengan menyiapkan ketersediaan fasilitas-fasilitas pendukung yang mencukupi untuk penyelenggaraan pendidikan dan kegiatan pesantren.

b) Ancaman

1) Pesantren sebagai the second choiceatau pilihan kedua dalam alternatif pendidikan dan pesantren hanya mengajarkan ilmu agama Islam saja adalah statemen masyarakat yang menjadi ancaman bagi pengelola pesantren. a) anggapan masyarakat yang selama ini berkembang memposisikan pesantren sebagai pilihan kedua juga merupakan ancaman bagi kelangsungan upaya pengembangan pesantren. b) anggapan masyarakat bahwa pendidikan dan kegiatan yang dikelola pesantren hanya berfokus pada kegiatan keagamaan saja, sehingga akan membatasi kreatifitas putra-putrinya untuk mengembangkan minat-bakatnya, ini juga ancaman bagi eksistensi pesantren. c) berdirinya sekolah berstandar nasional dan internasional, d) berdirinya lembaga/kursus pendidikan keterampilan dan profesi, pemikiran masyarakat yang ingin secara instan/cepat dalam proses pendidikan akan lebih memilih lembaga/kursus pendidikan berbasis keterampilan dan profesi untuk bisa diterima di dunia kerja. Hal ini juga bisa mengancam eksistensi pesantren yang secara umum penyelenggaraan pendidikannya relatif lebih lama. e) 
kekhawatiran berlebih dari masyarakat atas aturan-aturan pesantren yang ketat akan mengekang kebebasan putraputrinya, f) kurangnya pembelaan dari pemerintah atas anggapan masyarakat bahwa pesantren adalah sarang teroris, hal ini juga bisa menjadi ancaman serius bagi pengembangan pesantren untuk bisa lebih diterima masyarakat dunia luas. g) persaingan dunia kerja, jika pesantren tetap mempertahankan sistem upah pegawainya dengan bisyaroh yang nominalnya jauh lebih kecil dibandingkan gaji, maka hal ini juga bisa mengancam stabilitas penyelenggaran pendidikan dan kegiatan pesantren, karena bisa jadi pegawai akan lebih memilih mendedikasikan kemampuannya pada lembaga yang lebih bisa mensejahterakan kebutuhannya.

2) Pesantren adalah kawasan kumuh merupakan statemen masyarakat yang kurang menguntungkan dalam upaya pengembangan pesantren. a) anggapan masyarakat bahwa pesantren adalah kawasan yang kumuh, hal ini menjadi ancaman tersendiri, mengingat masyarakat dewasa ini cukup memperhatikan kesehatan dan kenyamanan dalam fasilitas pendidikan. Hal ini tampak jumlah santri pesantren Darussalam Blokagung mencapai 1.421 santri sedangkan fasilitas kamar yang tersedia hanya mencapai 198 kamar, maka ratarata per kamar dihuni oleh lebih dari 20-an santri, sedangkan ukuran kamar rata-rata hanya mencapai 3x3 meter. Kondisi inilah yang mendukung terciptanya kesan kumuh, karena kapasitas kamar yang overload(melebihi kapasitas). b) asumsi masyarakat bahwa fasilitas pesantren kurang memadai untuk pemenuhan dunia pendidikan, item ini juga merupakan hal yang kurang mendukung terhadap upaya pengembangan pesantren, mengingat lembaga-lembaga di luar pesantren terus berupaya menonjolkan model bangunan dan keindahannya untuk menarik simpati masyarakat. c) minimnya kendaraan umum yang beroperasi ke jalur pesantren, hal ini bisa mengancam akses dengan dunia luar untuk lebih bisa memperluas jaringannya dengan berbagai pihak yang mendukung upaya pengembangan pesantren. Kondisi lokasi pesantren Darussalam dari kota terdekatnya, yakni genteng 
\pm 12 kilo meter, sedangkan dari arah kota Jajag \pm 10 kilo meter, sedangkan kendaraan umum yang ada hanya ojek.

\section{Faktor internal yang mempengarubi pengembangan pesantren}

a) Kekuatan yang dimiliki oleh pesantren Darussalam: 1) Pesantren telah mengakar di masyarakat, 2) Kyai menjadi figur teladan, 3) Menyelenggarakan paket pendidikan yang lengkap dengan basis pendidikan agama dan umum dalam rangka pembinaan dan pendampingan kecerdasan intelektual, emosional serta spiritual. 4) Menyelenggarakan kegiatan keterampilan yang berorientasi pada penyaluran dan pengembangan minat-bakat. 5) Penerapan manajemen modern dalam pengelolaan pesantren, 6) Penerapan sistem sentralisasi dalam penyelenggaraan kegiatan pesantren dan pendidikan. 7) Penerapan manajemen keuangan sentral untuk operasional biaya penyelenggaraan kegiatan pesantren dan pendidikan. 8) Keterlibatan pengelola pesantren pada kegiatan sosial-keagamaan dan sosial politik. 9) Kepercayaan pemerintah dan swasta yang turut serta dalam upaya pengembangan pesantren, termasuk peningkatan pendidikan yang dikelola pesantren. 10) Mempunyai ikatan kuat dengan alumni dan wali santri yang terorganisir dalam penyelenggaraan kegiatan sosial. 11) Mempunyai usaha pereokonomian dalam mendukung eksistensi pesantren berupa koppontren (koperai pesantren) yang bersifat layanan jasa kepada santri dan masyarakat

b) Kelemahan yang dimiliki oleh pesantren Darussalam adalah: 1) Keterbatasan dalam memberikan kesejahteraan kepada pegawai, 2) Keterbatasan dalam kepemilikan anggaran pembangunan.

Strategi pengembangan yang tepat untuk diterapkan:

Strategi pengembangan yang tepat untuk diterapkan pada pesantren Darussalam adalah sebagai berikut ini: a)Menambah fasilitas kamar dan ruang pendidikan, b)Membatasi jumlah santri/ peserta didik dengan menetapkan kuota, c) Menambah anggaran biaya pelaksanaan pendidikan, d) Meminimalisir rangkap jabatan,e) Menyediakan failitas berupa transportasi menuju pesantren, f) Terus memajukan usaha perekonomian. 
Pondok Pesantren Bustanulmakmur Kebunrejo Genteng Banyuwangi

Pendiri Pesantren adalah KH Djunaidi Asymuni berasal dari desa Nampereh Kecamatan Galis Kabupaten Pamekasan pulau Madura. Hari jadi berdirinya pondok pesantren "Bustanul Makmur" Kebunrejo Genteng Banyuwangi, tepatnya pada tanggal 1 september 1947 Masehi. Pendidikan formal di yayasan Bustanul Makmur antara lain adalah: TK Khodijah 36, MI An - Nidhom dan SDI kebunrejo, MTs Kebunrejo dan SLTP Ma'arif khusus putri, Madrasah Aliyah Kebunrejo dan perguruan tinggi STIT Ibrahimy (berubah nama menjadi STAI Ibrahimy). Jumlah santri pesantren Bustanulmakmur Kebunrejo saat ini mencapai 185 santri.

\section{Faktor eksternal yang mempengaruhi pengembangan}

a) Peluang yang dimiliki antara lain: 1) Pengelolaan pesantren yang mengutamakan high moral adalah statemen masyarakat yang menguntungkan untuk menjaga citra tersebut dalam aktualiasasi pengembangan pesantren.2) Adanya bantuan dana dari pemerintah dan swasta untuk penyediaan pra sarana dan sarana pendidikan membantu pesantren dalam mencukupi keterbatasan anggaran dana pembangunan.

b) Ancaman yang dimiliki antara lain: 1) Pesantren sebagai the second choice atau pilihan kedua dalam alternatif pendidikan dan pesantren hanya mengajarkan ilmu agama Islam saja adalah statemen masyarakat yang menjadi ancaman bagi pengelola pesantren.2) Pesantren adalah kawasan kumuh merupakan statemen masyarakat yang kurang menguntungkan dalam upaya pengembangan pesantren.

\section{Faktor internal yang mempengarubi pengembangan}

a) Kekuatan yang dimiliki adalah: 1) Pesantren telah dikenal oleh masyrakat, 2) Kharismatik kyai sebagai tokoh sentral pesantren. 3) Masih kental kultur Madura di lingkungan pesantren, 4) Menyelenggarakan paket pendidikan agama dan umum sekaligus, 5) Lokasi strategis yang dimiliki oleh pesantren Bustanulmakmur juga menjadi daya tarik tersendiri. 
b) Kelemahan yang dimiliki adalah: 1) Tidak ada pengasuh utama/ ketua dewan pengasuh. 2) Manajemen penyelenggaraan pendidikan tidak sentral. 3) Tidak menerapkan manajemen keuangan sentral. Hal ini dilatarbelakangi oleh penyelenggaraan lembaga pendidikan yang juga tidak bersifat sentral.4) Areal terbatas, 5) Ketidakseimbangan jumlah santri dan peserta didik..

\section{Strategi pengembangan yang tepat untuk diterapkan}

Strategi pengembangan yang tepat untuk pesantren ini adalah sebagai berikut: a) Menerapkan sistem manajemen sentral pada seluruh pendidikan yang dikelola, b) Menerapkan sistem keuangan sentral, c) Perlu menetapkan ketua dewan pengasuh sebagai sentral pemimpin pesantren, d) Menambah areal pemukiman santri dengan cara bangunan bertingkat di area pusat, e) Menambah jenis kegiatan ketrampilan untuk santri.

\section{Pondok Pesantren Mamba'ulhuda Krasak Tegalsari Banyuwangi}

Pondok Pesantren Mamba'ul Huda yang berada di Krasak, Tegalsari, Banyuwangi, Jawa Timur didirikan oleh KH. Abdul Majid pada tanggal 17 Agustus 1944 (data piagam pesantren dan akta notaris Yayasan Pondok Pesantren Mamba'ul Huda). Untuk mengakomodasi itu, dikembangkanlah unit-unit kegiatan yang relevan dengan kebutuhan santri dan pesantren. Madrasah Diniyah Miftahul Huda menjadi unit formal pertama yang dibangun di sini (tahun 1954). Menyusul kemudian MI, TK, MTs. Mamba'ul Huda (1989), SMK Negeri (2005), PAUD dan Madrasah Aliyah (MA) Unggulan Mamba'ul Huda (Rabu, 22 Juli 2009) serta lembaga-lembaga lainnya. Karena unit-unit terus bertambah dan berkembang, maka dibentuklah Yayasan Pondok Pesantren Mamba'ul Huda (YPPMH) pada tanggal 14 Rajab 1408 H, bertepatan dengan 29 Maret 1988. Dengan berdirinya Yayasan, maka unit-unit yang ada di lingkungan Pondok Pesantren Mamba'ul Huda menjadi unit-unit Yayasan. Jumlah santri pesantren Mamba'ulhuda Krasak saat ini mencapai 436 santri

\section{Faktor eksternal yang mempengarubi pengembangan}

a) Peluang yang dimiliki antara lain: 1)Pengelolaan pesantren yang mengutamakan high moral adalah statemen masyarakat yang 
menguntungkan untuk menjaga citra tersebut dalam aktualiasasi pengembangan pesantren.2) Adanya bantuan dana dari pemerintah dan swasta untuk penyediaan pra sarana dan sarana pendidikan membantu pesantren dalam mencukupi keterbatasan anggaran dana pembangunan.

b) Ancaman yang dimiliki antara lain: 1) Pesantren sebagai the second choice atau pilihan kedua dalam alternatif pendidikan dan pesantren hanya mengajarkan ilmu agama Islam saja adalah statemen masyarakat yang menjadi ancaman bagi pengelola pesantren. 2) Pesantren adalah kawasan kumuh merupakan statemen masyarakat yang kurang menguntungkan dalam upaya pengembangan pesantren.

\section{Faktor internal yang mempengarubi pengembangan}

a) Kekuatan yang dimiliki antara lain: 1) Pesantren telah dikenal oleh masyrakat luas, 2) Menyelenggarakan paket pendidikan agama dan umum sekaligus, 3) Memiliki pemimpin yang adaptif terhadap perubahan, 3) Mempunyai jaringan alumni yang baik, 4) Melakukan pendekatan dan kerjasama yang baik dengan tokoh masyarakat melalui pelibatan pada susunan kepengurusan yayasan pesantren Mamba'ulhuda, sehingga eksistensi dan pengembangan yayasan pesantren Mamba'ulhuda tidak hanya menjadi tanggungjawab keluarga pendiri, tetapi juga menjadi tanggungjawab masyarakat secara umum.

b) Kelemahan yang dimiliki adalah: 1) Manajemen penyelenggaraan pendidikan tidak sentral. 2) Tidak menerapkan manajemen keuangan sentral. 3) Ketidakseimbangan jumlah santri dan peserta didik. Dari data yang terdokumentasikan, pesantren Mamba'ulhuda Krasak saat ini memiliki jumlah santri 669, sedangkan jumlah peserta didiknya mencapai jumlah 3025. Ketimpangan ini disebabkan kebijakan pesantren yang tidak bisa masuk pada lembaga pendidikan yang dikelola, karena masingmasing lembaga pendidikan mempunyai otoritas dalam penyelengaraan pendidikannya. 4) Pengambilalihan SMK Mamba'ulhuda menjadi SMKN Tegalsari menyebabkan, lembaga pendidikan yang dirintis oleh pesantren Mamba'ulhuda ini tidal lagi menjadi binaan pesantren, akan tetapi menjadi binaan peme- 
rintah, dalam hal ini khususnya adalah Pemerintah Daerah Kabupaten Banyuwangi. Sehingga yang seharusnya alih status swasta menjadi negeri tersebut menjadi daya tarik peserta didik untuk menjadi santri pesantren, ternyata menjadi polemik pada pembinaan pendidikan santri di pesantren. Karena ketidaksamaan waktu pelaksanaan pendidikan di SMKN dengan lembaga pendidikan umum lainnya yang dikelola pesantren menyebabkan peserta didik yang menjadi santri kegaiatan pendidikan agamanya di pesantren diatur dengan jadual khusus dan ada beberapa kegiatan yang tidak diikuti akibat padatnya kegiatan di SMKN. 5) adanya rangkap jabatan oleh pegawai, 6) minimnya anggaran pembangunan, 7) Keberadaan ketua yayasan yang tidak mukim di lokasi pesantren, sehingga tidak bisa melakukan pendampingan intensif pada kegiatan santri di pesantren dan terkesan lebih berkonsentrasi pada pengelolaan lembaga pendidikan umum.

\section{Strategi pengembangan yang tepat untuk diterapkan}

Strategi pengembangan yang tepat untuk pesantren ini adalah sebagai berikut:1) Menerapkan sistem manajemen sentral pada seluruh pendidikan yang dikelola, 2) Menerapkan sistem keuangan sentral, 3) Menambah fasilitas kamar dan ruang pendidikan,4) Membatasi jumlah santri/peserta didik dengan menetapkan kuota,5) Menambah anggaran pembangunan, 6) Meminimalisir rangkap jabatan, karena menyebabkan kurangnya fokus kinerja dan meminimalisir kecemburuan sosial yang bisa muncul dari pegawai/lembaga pendidikan lain di pesantren.7) Menambah jenis kegiatan ketrampilan untuk santri, 8) Ketua yayasan akan menjadi harus bermukim di lokasi pesantren, karena keberadaannya tidak hanya menjadi pengawas kegiatan santri, khususnya di pesantren, akan tetapi juga menjadi bagian dari inspirai santri dalam laku keteladanan pribadi santri.

Pondok Pesantren Mamba'ululum Sumberberas Muncar Banyuwangi

Perintisan Pondok Pesantren Mambaul Ulum adalah KH. Askandar Pesantren yang secara resmi berdiri pada tahun 1934 
jauh sebelum kemerdekaan Indonesia ini. Pondok Pesantren Mambaul Ulum Dusun Berasan Kecamatan Muncar Kabupaten Banyuwangi Propinsi Jawa Timur. Jumlah santri pesantren Mamba'ululuum Muncar mencapai 817 santri sedangkan fasilitas kamar yang tersedia hanya mencapai 40 kamar, maka rata-rata per kamar dihuni oleh lebih dari 20-an santri, sedangkan ukuran kamar rata-rata hanya mencapai $4 \times 3$ meter. Selain lembaga pendidikan agama melalui madrasah diniyah juga telah menyelenggarakan lembaga pendidikan umum mulai pendidikan anak usia dini sampai perguruan tinggi dan diantara lembaga pendidikan tersebut adalah lembaga pendidikan unggulan, yakni sekolah menengah pertama (SMP) Unggulan dan SMKN yang pada mulanya dirintis oleh pesantren dengan nama SMK Darululuum. STAI Darululuum

\section{Faktor eksternal yang mempengarubi pengembangan}

a) Peluang yang dimiliki adalah: 1) Pengelolaan pesantren yang mengutamakan high moral adalah statemen masyarakat yang menguntungkan untuk menjaga citra tersebut dalam aktualiasasi pengembangan pesantren.2) Adanya bantuan dana dari pemerintah dan swasta untuk penyediaan pra sarana dan sarana pendidikan membantu pesantren dalam mencukupi keterbatasan anggaran dana pembangunan.

b) Ancaman yang dimiliki adalah:1) Pesantren sebagai the second choice atau pilihan kedua dalam alternatif pendidikan dan pesantren hanya mengajarkan ilmu agama Islam saja adalah statemen masyarakat yang menjadi ancaman bagi pengelola pesantren.2) Pesantren adalah kawasan kumuh merupakan statemen masyarakat yang kurang menguntungkan dalam upaya pengembangan pesantren.

\section{Faktor internal yang mempengarubi pengembangan}

a) Kekuatan yang dimiliki adalah: 1) Pesantren telah lama dikenal oleh masyrakat, 2) Pesantren memiliki jaringan luas dengan pemerintah daerah, wilayah maupun pusat. Hal ini karena pengasuh pesantren ada yang pernah menjabat sebagai wakil bupati Banyuwangi yakni, KH Yusuf Nuris dan KH Nur Muhammmad Iskandar yang memiliki kedekatan dengan menteri 
Agama dan Menteri Pendidikan Republik Indonesia, karena dipercaya menjadi mediator pemerintah dengan lembaga pesantren di Indonesia.

b) Kelemahan yang dimiliki adalah:1)Tidak ada pengasuh utama/ ketua dewan pengasuh. Saat ini pesantren Mamba'ululuum dipimpin oleh dewan pengasuh yang beranggotakan: 1) $\mathrm{KH}$ Imam Baidlowi Askandar, Kyai Ali Hasan Syadzili dan Kyai Abdul Rouf Ali Manan. Kondisi ini mempengaruhi kelemahan kebijakan yang diterapkan di pesantren, selain juga koordinasi organisasi pesantren yang kurang fokus, karena tidak diimbangi dengan pembagian kewenangan kebijakan.2)Manajemen penyelenggaraan pendidikan tidak sentral. 3) Tidak menerapkan manajemen keuangan sentral. 4) Ketidakseimbangan jumlah santri dan peserta didik. Dari data yang terdokumentasikan pesantren Mamba'ululuum saat ini memiliki jumlah santri 817, sedangkan jumlah peserta didiknya mencapai jumlah 2598. 5) Pengambilalihan SMK Darululuum menjadi SMKN Muncar menyebabkan, lembaga pendidikan yang dirintis oleh pesantren Mamba'uluum ini tidal lagi menjadi binaan pesantren, akan tetapi menjadi binaan pemerintah, dalam hal ini khususnya adalah Pemerintah Daerah Kabupaten Banyuwangi, karena diantara dampak negatif yang ditimbulkan adalah tingginya minat masyarakat terhadap SMKN Muncar, tetapi minat masyarakat pada pendidikan pesantren menjadi rendah. Apalagi dengan pengambilalihan status tersebut menyebabkan pesantren tidak lagi mempunyai kewenangan terhadap pengelolaan SMKN.6) adanya rangkap jabatan oleh pegawai, 7) minimnya anggaran pembangunan.

\section{Strategi pengembangan yang tepat untuk diterapkan}

Strategi pengembangan yang tepat untuk pesantren ini adalah sebagai berikut:1) Menerapkan sistem manajemen sentral pada seluruh pendidikan yang dikelola, karena hakikatnya tanpa adanya pesantren sebagai lembaga yang berbentuk yayasan, seluruh lembaga pendidikan tersebut tidak bisa berdiri. Maka menjadi tanggungjawab pesantren untuk mempertahankan eksistensi lembaga pendidikan tersebut, termasuk pengembangannyaa dengan 
memberikan perhatian yang sama antar lembaga pendidikan.2) Menerapkan sistem keuangan sentral, 3) Perlu menetapkan ketua dewan pengasuh sebagai sentral pemimpin pesantren, karena bagaimanapun jika organisasi, teramasuk dalam hal ini organisasi pesantren yang tidak memiliki pemimpin sentral terhambat pengembangannya, 4) Menambah anggaran pembangunan,5) Meminimalisir rangkap jabatan, 6) Menambah jenis kegiatan ketrampilan untuk santri, dari daftar kegiatan ekstra kurikuler yang ada, masih sangat terbatas akomodir minat-bakat santri dalam kegiatan keterampilan. Maka ragam kegiatan keterampilan perlu diciptakan agar kreatifitas santri bisa tersalurkan dengan baik.

\section{Pondok Pesantren Darussholah Gumirih Singojurub Banyuwangi}

Berdirinya Pondok Pesantren Darussholah Singojuruh,adalah merupakan bagian dari kisah nyata yang diilhami dari tokoh Ulama' Besar di Banyuwangi KH. Mukhtar Syafa'at Abdul Ghofur Pendiri dan Pengasuh Pondok Pesantren Darussalam Blokagung. Beliau menyampaikan kepada KH. Nurfauzi (Santri KH. Mukhtar Syafa'at) dalam acara silaturrohmi, Beliau mengatakan "Besok selatan rumah kamu (Ndalem) tolong dijadikan Masjid dan dikelilingi asrama santri, dan Pondok ini akan berkembang mengarah ke timur, dengan petunjuk KH. Muhtar Syafa'at tersebut, KH. Nurfauzi bertanya-tanya dalam benak hati, "darimana ada santri?" tapi pertanyaan tersebut hilang berubah menjadi kemantapan dan keyaqinan bahwa ini merupakan petunjuk Allah lewat sang Guru.Pada tanggal 17 April 1988 M dengan susah payah dan bantuan masyarakat Gumirih Singojuruh Pondok Pesantren Darussholah di dirikan. Kemudian pada tanggal tersebut (17 April 1988 M ) didirikan pula Yayasan dengan nama "Yayasan Darussholah" yang kelak menjadi payung dari segala aktifitas yang ada, baik aktifitas pendidikan atau sosial,serta membentuk susunan kepengurusan. Untuk menguatkan kredibilitas dan status Yayasan di Masyarakat, Instansi dan Publik atas berdirinya lembaga tersebut, maka pada tanggal 08 September 2004 M lembagadi Akte Notariskan di Notaris Muttaqien, SH dengan nomor Notaris 29.Selanjutnya, dengan semakin banyaknya santri yang masuk di Pondok Pesantren Darussholah dan kebutuhan masyarakat sekitar akan pendidika formal tingkat Sekolah menengah 
Atas maka pada tanggal 22 Juni 2003 diresmikan berdirinya SMA Negeri Darussholah Singojuruh.Pesantren Darussholah Gumirih yang saat ini memiliki santri sejumlah 139 santri mukim dan 200 santri yang tidak mukim. Di pesantrentelah menyediakan kamar sebagai tempat mukim santri sejumlah 31 kamar dengan ukuran 4x3 meter.

\section{Faktor eksternal yang mempengarubi pengembangan}

a) Peluang yang dimiliki adalah : 1) Pengelolaan pesantren yang mengutamakan high moral adalah statemen masyarakat yang menguntungkan untuk menjaga citra tersebut dalam aktualiasasi pengembangan pesantren.2) Adanya bantuan dana dari pemerintah dan swasta untuk penyediaan pra sarana dan sarana pendidikan membantu pesantren dalam mencukupi keterbatasan anggaran dana pembangunan.

b) Ancamanyang dimiliki adalah :1) Pesantren sebagai the second choice atau pilihan kedua dalam alternatif pendidikan dan pesantren hanya mengajarkan ilmu agama Islam saja adalah statemen masyarakat yang menjadi ancaman bagi pengelola pesantren.2) Pesantren adalah kawasan kumuh merupakan statemen masyarakat yang kurang menguntungkan dalam upaya pengembangan pesantren.

\section{Faktor internal yang mempengarubi pengembangan}

a) Kekuatan yang dimiliki adalah : 1)Pesantren telah mengakar di masyarakat, 2) Menyelenggarakan paket pendidikan agama dan umum sekaligus, hal ini juga menjadi sebab ketertarikan masyarakat pada pesantren. 3) Memiliki pemimpin yang adaptif terhadap perubahan, dalam hal ini adalah Agus Afuwung Karim yang menjadi ketua umum pesantren Darussholah Gumirih. Kepemimpinannya mampu membawa pesantren ini mengembangkan lembaga pendidikan, sehingga pesantren yang awal dibentuknya hanya menyelenggarakan lembaga pendidikan agama sebagai bagian dari konsekuensi kesalafan pesantren mulai berkembang menjadi salaf-modern karena mempertahankan lembaga pendidikan agama dan menambah lembaga pendidikan umum. 
b) Kelemahan yang dimiliki adalah : 1) Kurang adanya dukungan dari pemerintah desa, tokoh masyarakat dan tokoh agama pada perkembangan pesantren. Hal ini tampak pada rendahnya loyalitas dan solidaritas mereka pada kegiatan pendidikan pesantren dengan membatasi akses pesantren pada masyarakat. 2) Kerjasama yang kurang baik antara pengurus yayasan dan pengurus pesantren. Dari awal berdirinya hingga saat ini pengurus yayasan dipercayakan kepada masyarakat sekitar pesantren dalam rangka menarik simpati dan perhatian mereka terhadap pesantren, akan tetapi pada kenyataannya pengurus yayasan tidak bisa melakukan koordinai dan komunikasi yang baik dengan pengurus pesantren, bahkan terkesan menghambat perkembangan pesantren. 3) Ketidakseimbangan jumlah santri dan peserta didik. 4) Pengambilalihan SMA Darussholah menjadi SMAN menyebabkan, lembaga pendidikan yang dirintis oleh pesantren Darussholah ini tidal lagi menjadi binaan pesantren, akan tetapi menjadi binaan pemerintah, dalam hal ini khususnya adalah Pemerintah Daerah Kabupaten Banyuwangi. Sehingga yang seharusnya alih status swasta menjadi negeri tersebut menjadi daya tarik peserta didik untuk menjadi santri pesantren, ternyata menjadi polemik pada pembinaan pendidikan santri di pesantren. Karena diantara dampak negatif yang ditimbulkan adalah tingginya minat masyarakat terhadap SMAN, tetapi minat masyarakat pada pendidikan pesantren menjadi rendah. Apalagi dengan pengambilalihan status tersebut menyebabkan pesantren tidak lagi mempunyai kewenangan terhadap pengelolaan SMAN karena otoritas penuh ada pada pemerintah, khususnya Pemerintah Daerah. 5) adanya rangkap jabatan oleh pegawai, bagaimanapun rangkap jabatan memberikan pengaruh kurang baik pada profesionalitas pegawai karena konsentrasinya tidak lagi fokus terhadap satu pekerjaan, hasilnya kinerjanya menjadi kurang maksimal. 6) Kurang beragamnya jenis pendidikan umum yang dikelola. 7) Kurang tersedianya variasi kegiatan keterampilan santri yang tidak hanya bernuansa Islami tetapi juga bernuansa umum. 
Abdul Kholiq Syafa'at, dkk.

Strategi pengembangan yang tepat untuk diterapkan

Strategi pengembangan yang tepat untuk pesantren ini adalah sebagai berikut: 1) Melakukan konsolidasi dengan pemerintah desa untuk membangun kerjasama yang baik, bisa juga dengan pelibatan pihak lain sebagai mediator untuk menjembatani minimnya komunikasi dan koordinasi antara pesantren dan pemerintah desa. 2) Perlunya pembaruan kepengurusan di tingkat yayasan bertolak dari evaluasi kinerjanya selama ini dengan duduk bersama yang bertujuan untuk pengembangan pesantren ke depan, 3) Menambah jenis pendidikan umum yang dikelola pesantren sebagai daya tarik mayarakat pada pesantren. 4) Meminimalisir rangkap jabatan, karena menyebabkan kurangnya fokus kinerja dan meminimalisir kecemburuan sosial yang bisa muncul dari pegawai dan lembaga pendidikan lain di pesantren. 5) Menambah jenis kegiatan ketrampilan untuk santri, dari daftar kegiatan ekstra kurikuler yang ada, masih sangat terbatas akomodir minat-bakat santri dalam kegiatan keterampilan. Maka ragam kegiatan keterampilan perlu diciptakan agar kreatifitas santri bisa tersalurkan dengan baik.

\section{Kesimpulan}

Kesimpulan dalam penelitian ini adalah sebagai berikut:Faktor eksternal dalam hal ini dibagi menjadi 2, yaitu: 1)Peluang atau kesempatan diantaranya; adanya kepercayaan masyarakat kepada pesantren dan adanya perhatian dari pihak pemerintah dan swasta. 2)Ancaman diantaranya; adanya anggapan masyarakat bahwa pesantren dengan lembaga pendidikan yang diselenggarakannya merupakan the second choice dan pesantren merupakan kawasan kumuh.

Faktor internal dalam hal ini dibagi menjadi 2, yaitu: 1) Kekuatan antara lain; pesantren telah mengakar di masyarakat dan predikat "The High Moral' yang dimiliki oleh pesantren, serta kyai sebagai figur teladan. 2)Kelemahan antara lain; penerapan manajemen yang kurang profesional, Sumber Daya Insani yang rendah dan pengelolaan Sumber Daya Alam pesantren yang kurang optimal, serta sikap inklusif pengelola pesantren. 
Strategi pengembangan yang tepat untuk diterapkan pesantren di Kabupaten Banyuwangi:

1) Strategi pengembangan lembaga pendidikan Islam ada 2, yaitu:

a) Konsisten, dengan peluang dan kekuatan yang dimiliki oleh pesantren berupa kepercayaan dari masyarakat sebagai lembaga pendidikan berbasis pendidikan moral, sekaligus adanya kyai sebagai tokoh sentral pesantren dengan kharisma serta kelebihan lain yang dimiliki mampu menjadi daya tarik masyarakat untuk mendaftarkan putra-putrinya belajar di pesantren, maka sudah seharusnya pesantren berupaya sedemikian rupa mewujudkan asumsi masyarakat, bahwa pesantren layak menyandang predikat The High Moral. Adapun caranya dengan mempertahankan sistem pendidikan yang telah diselenggarakannya selama ini yakni pendidikan berbasis keagamaan melalui madrasah diniyah yang disebut sebagai ruhnya pesantren. Hal inilah yang selaras dengan konsep almubafadbotu 'alaa al-qodiimi as-shoolih (mempertahankan sitem lama yang baik).

b) Adaptif, untuk bersaing dengan lembaga pendidikan non pesantren baik yang dibina oleh pemerintah maupun swasta, maka pesantren melalui lembaga pendidikan Islam yang dikelolanya harus mau membuka diri dengan cara transformasi pendidikan, misalnya dengan sistem pendidikan yang berbasis IT yang memungkinkan lembaga pendidikan Islam tersebut mampu menerapkan variasi metode pembelajaran dengan media visual maupun audio visual dan pada akhirnya bisa menciptakan suasanan pembelajaran aktif, inovatif, kreatif, efektif dan menyenangkan (PAIKEM). Kondisi inilah yang sebenarnya selaras dengan konsep wa al-akhdu bi aljadiid al-ashlah (mengambil sistem baru yang lebih baik).

2) Strategi pembaruan manajemen pesantren

Selama ini pesantren sangat kental dengan manajemen tradisionalnya. Hal ini tampak pada struktur kepemimpinan pesantren serta personalia pengelolanya yang cenderung atas restu dari kyai sepuh yang menjadi pengasuh utama pesantren. Keadaan 
ini membawa dampak diantaranya: pengambilan keputusan/ kebijakan, penentuan ustadz/ustadzahnya, termasuk kinerjanya hanya berorientasi pada pengabdian, sehingga berakibat pada peningkatan kinerja yang rendah. Oleh karena itu untuk memperbarui manajemen pesantren harus ada wacana baru yang berupa penerapan manajemen profesional, diantaranya rekuitment pegawai harus melalui tes kemampuan, kepemilikin latar belakang pendidikan yang mendukung dengan ketrampilannya selain tingkat kepatuhan kepada kyai (mengikuti aturan pesantren). Dengan demikian akan terbangun kualitas pelayanan pendidikan yang baik sehingga bisa meningkatkan mutu lembaga pendidikan Islam di pesantren.

3) Strategi peningkatan sumber daya pesantren ada 2, yaitu:

a) Peningkatan Sumber Daya Insani, diantaranya dengan memberikan pembinaan mendatangkan tim ahli sesuai dengan bidang yang dibutuhkan, mengadakan pelatihan yang mendukung pada peningkatan kreatifitas sumber daya insani bahkan bisa dengan memberikan rekomendasi beasiswa untuk melanjutkan pendidikan melalui kerjasama dengan pihak pemerintah maupun swasta.

b) Peningkatan Sumber Daya Alam, pesantren sebagai lembaga pendidikan Islam mandiri sudah seharusnya mampu mengoptimalkan aset yang dimilikinya agar bisa dimanfaatkan sepenuhnya untuk meningkatan eksistensinya. Diantara cara yang bisa ditempuh adalah mengembangkan Koperasi Pesantren melalui berbagai unit usahanya (berupa jasa pelayanan, baik untuk santri maupun masyarakat) dalam rangka memenuhi operasional penyelenggaran pendidikan pesantren. Adapun pengelolaan Koperasi Pesantren tersebut harus dengan manajemen profesional dan berbadan hukum secara resmi agar perkembangannya tidak mendapat hambatan, baik hambatan yang datang dari pemerintah maupun swasta. 


\section{Daftar Pustaka}

A'la, Abdul. 2006. Pembaharuan Pesantren. Yogyakarta: Pustaka Pesantren ('eLKIS)

Masyhud,Sulthon \&Ridlo. 2005. Manajemen Pondok Pesantren, Jakarta: Diva Pustaka.

Qomar, Mujamil. 2007. Manajemen Pendidikan Islam-strategi Baru Pengelolaan Lembaga Pendidikan. Penerbit: Erlangga

Sihombing, Umberto. 2000. Manajemen Strategi, Jakarta: Mahkota.

Syam, Nur. 2005. Penguatan Kelembagaan Ekonomi Bebasis Pesantren, Yogyakarta: Pustaka Pesantren.

Suwendi, RA. 2004. SejarahEPemikiran $\square$ Pendidikan Islam. Jakarta: Gravindo Persada

Tholkhah, Imam dan Barizi, Ahmad. 2004. Membuka Jendela Pendidikan. Jakarta: Raja Grafindo Persada 